\title{
Analysis of Factors Enhancing Pitfall in Research and Teaching of the Nigerian University System
}

\author{
Dr. Tafida Ahmed ${ }^{1}$, Dr. Kasim Umar ${ }^{1} \&$ Dr. Chima Paul ${ }^{1}$ \\ ${ }^{1}$ Department of Public Administration, Faculty of Management Sciences, University of Abuja, Nigeria \\ Correspondence: Dr. Chima Paul, Department of Public Administration, Faculty of Management Sciences, \\ University of Abuja, Nigeria. E-mail: chimapaul2006@yahoo.com
}

Received: November 13, 2014

Accepted: June 9, 2015

Online Published: July 10, 2015

doi:10.5430/ijhe.v4n3p82

URL: http://dx.doi.org/10.5430/ijhe.v4n3p82

\begin{abstract}
The paper analyses factors enhancing pitfall in research and teaching in the Nigerian university system. Using data generated from secondary sources, it was found that so many factors are responsible for the constant decay in teaching and research in the Nigerian universities. The paper however found from literature that the high rate of pitfalls in the university education in Nigeria can be significantly attributed to lack of infrastructural facilities, poor staffing and inadequate funding. Consequently, the paper suggests the way forward which includes: provision of adequate and modern facilities (like modern class rooms, computers, modern libraries etc), adequate funding which can be provided through collaboration and partnership with universities abroad and improved creativity in the area of generation and utilization of internal revenues, and finally, attraction of high quality teachers with better salary and good conditions of service into the Nigerian universities.
\end{abstract}

Keywords: Pitfall, Research, Teaching, Nigeria, University

\section{Introduction}

Nigeria is a country located on the South Coast of West Africa. It has thirty six states with a Federal Capital Territory. Nigeria has an estimated population of over one hundred and fifty million people. As a responsible country with the zeal to enhancing the quality of these people and also to have a knowledge construction economy, several universities were established. Currently, Nigeria has over one hundred universities in existence. In fact, Nigeria has the largest universities in the Sub-Sahara Africa. Precisely, Nigeria has 129 Universities (Yusuf, 2014) including public and private ones. Though these universities were set up with the intension to contribute richly to the socio-economic and cultural development of the Nigerian state, unfortunately, the series of the academic activities such as teaching, researches, community services being carried out in these universities are not measuring up with the public expectations of them. In other words, these universities are performing below average standard. In the global ranking of Universities, none of the Nigerian Universities appeared in the list of the top 6,000 Universities in the world (Oyeneye, 2006). This development appears very irritating when viewed against the backdrop that Nigeria once served as the nucleus of university education in the West-African sub-region.

Several factors such as work environment, improper curriculum, lack of proper communication and so on have been mentioned as factors responsible for the pitfall in the Nigeria university system. No doubt, the afore-mentioned factors are not unconnected with the poor performance of university system in Nigeria. However, the position of this study is that, if adequate funding, infrastructure and proper staffing are in place, invariably, the negative effects of the foregoing barriers mentioned can easily be cushioned. Therefore, it is argued in this paper that the high rate of pitfall in the university education in Nigeria can be significantly attributed to lack of infrastructural facilities, poor staffing and inadequate funding. This study therefore, is a critical analysis of how these factors (infrastructural facilities, poor staffing and inadequate funding) have contributed to the pitfall in research and teaching in the Nigerian university system. The paper concentrates on the critical issues (research and teaching) because the major function of University education is capacity building to be facilitated through quality teaching and research.

In an attempt therefore to achieve the aim of this paper, it is divided into the following sections. Section one is the history of the Nigerian university system. The second section deals with situational analysis of research and teaching in the Nigerian university system. Section three focuses on the analysis of the factors responsible for the pitfall. 
The subsequent section is the discussion of results. The final section focused on the conclusion and recommendations.

\section{Historical Development of the Nigeria University System}

The establishment of the University College Ibadan in 1948 which was an affiliate of University of London marked the beginning of University education in Nigeria. The College became full-fledged University in 1962. The birth of this university led to the creation of the first generation universities, namely, University Of Nigerian Nsukka created in 1960 and University of Ife, Ahmed Bello University, University of Lagos which were created in 1962 except University of Benin that was established in 1970. These universities were created by the various regional governments then. The legal backing for these achievements was derived from the Oliver Littleton constitution of 1954 which eventually made it possible for the regional governments to make their own educational law.

The need to create more universities in Nigeria culminated in the emergence of the second generation universities. List of universities that belong to the second generation of universities in Nigeria are Ado Bayero University Kano, University of Calabar, University of Ilorin, University of Jos, University of Maiduguri, University of Portharcourt and Usmandanfodio University, Sokoto. The major characteristic of this period was that, the creation of universities in Nigeria was the sole responsibility of the Federal Government of Nigeria. In other words, university educational affairs were contained in the exclusive list. What the foregoing means is that all the first and second generation universities were Federal Government owned. However, with the coming to effect of the 1979 Constitution of the Federal Republic of Nigeria, University education was transferred from Exclusive List to Concurrent List. In due course, the states immediately began to utilize this constitutional opportunity to establish their own Universities. The involvement of the State Governments in the establishment of Universities in the country was pioneered by the old Rivers State Government with the establishment of Rivers State University of Science and Technology. Other States of the Federation which do not exclude Bendel State University, Imo State University, Ondo State University, and others in Ogun, Cross River, Anambra, and Lagos States joined in the establishment of university education from 1979 - 1983 (Magida, 2013).

There are other universities created by the Federal Government of Nigeria which were recently established since 2011 till present, to give sense of belonging to a number of States in Nigeria that are yet to have a Federal presence in terms of University education, and also to make university education accessible to all the nooks and cranny of the country. Federal Universities created within these categories were in Lokoja, Kogi State, Lafia, Nasarawa State; Kashere, Gombe State; Wukari, Taraba State; Dutsin-Ma, Katsina State; Dutse, Jigawa State and Ndufu-Alike, Ebonyi State. Other are Federal Universities Birnin-Kebbi, Kebbi State; Gusau, Zamfara; Gashua, Yobe; Oye- Ekiti, Ekiti State; Otuoke, Bayelsa State. Apart from the federal and the state own universities, there are well over 47 private universities in Nigeria. In all, Nigeria has well over a hundred universities. The goals of the Nigerian universities includes among others to:

i. Contribute to national development through high level relevant manpower training;

ii. Develop and inculcate proper values for the survival of the individual and society;

iii. Develop intellectual capability of individuals to understand and appreciate their local and external environments;

iv. Acquire both physical and intellectual skills which will enable individuals to be self-reliant and useful members of the society;

v. Promote and encourage scholarship and community service;

vi. $\quad$ Forge and cement national unity and;

vii. Promote national and international understanding and interaction (FRN, 2004). Notwithstanding the historical analysis of the proliferation of the university system, the major issue before this paper is that, have these universities been performing up to what is required of them with respect to research and teaching, the primary objectives of every university the world over. This takes us to the situational analysis of the research and teaching in the Nigeria university system.

\section{Situational Analysis of Research and Teaching in the Nigerian University System}

\subsection{Research Output}

Universities in particular among other higher educational institutions are bestowed with the responsibilities to carryout quality research that will have positive impact on the national development. This implies that one of the 
fundamental factors for measuring the worth of University education is the quality of research emanating from the system. It is very fundamental because University system can gainfully obtain vital information through research. In the course of research work, universities can provide vital researched information for the labour market and provide skilled workers on the areas of needs in the immediate environment and outside world. But there has been a precipitation fall in the quality and quantity of research outputs of the Nigerian university system. The decline in research productivity in higher education \{university system\} in Nigeria became noticeable in the late 1980s. The National University Commission (NUC) noted that in terms of quality and quantity, the research output of tertiary institutions in Nigeria was about the best in sub-Saharan Africa up to the early 1980s (Karani, 1997). During this period, Nigerians became more widely known for their research, the products of which they strived to showcase on the international intellectual scene (Nduka and Falayojo, 1985). This research output occurred in all the branches of science and in all fields of human endeavour. But sooner than later, the research outputs declined in the Nigerian universities as can be seen below.

In measuring research output, Cetto (1998) suggested using some parameters. This include the number and quality of published works by Nigerians in international journals, and by the world distribution of active serial titles emanating from the universities, which contribute to the generation, dissemination, and application of scientific knowledge for development in Nigeria and beyond. Applying this index to the situational analysis of the research, Nigeria's number of scientific publications for 1995 was 711 - significantly less than its output of 1,062 scientific publications in 1981 by a comparatively much smaller university system. About this same period, scientific publications for South Africa were 3,413, 14,883 for India, 310 for Indonesia, and 5,440 for Brazil (TASK FORCE, 2000). The country's low research output probably reflects the low priority accorded to research and development by government decision-makers. For example, Nigeria's Federal University system spends only $1.3 \%$ of its budget on research (HARTNETT 2000). Further comparison shows that Nigeria has 15 scientists and engineers engaged in research and development (R\&D) per million persons; India has 158; Brazil has 168 per million, China has 459, while the United States has 4,103 (Aluko and Aluko, 2012). It is doubtful if Brazil and India graduate as many scientists and engineers annually in proportion to their populations as Nigeria, yet the gap in the number engaged is so wide. Okafor (cited in Yusuf, 2012) recently carried out a comparative analysis of research output of six federal universities in Southern Nigeria (University of Benin, University of Ibadan, University of Agriculture, Abeokuta, Nnamdi Azikwe University, University of Nigeria, Nsukka and University of Uyo) in the period 1997-2006 based on both local and international publications, and found that the highest research output of 12.17 publications per head was recorded at the University of Benin and the lowest of 8.13 at the University of Uyo over the ten-year period. Worthy of note here is that even the best case scenario of a mean of 12.17 translates to only about one publication per academic staff per year. Though researches were in low quantity as at this time, but the qualities were highly commendable. But in recent times, a large number of research output were churned out of the Nigeria university system but the qualities left much to be desired. Commenting on the horrible quality of research in Nigeria, Yusuf (2012) lamented thus:

The "publish or perish" syndrome associated with the higher education system in general and the university system in particular could be said to have plunged academics in these institutions into a career-long survival race for promotions and positions within their institutional hierarchies and perhaps beyond. For an academic to survive in such a race, they must obtain desperately needed publications to their credit through research and/or creative development. This means that the primary motive of competing in this race is no more than that of career prospects and intellectual prestige. The point being made here is that by orientation, content and primary intent, the bulk of research going on in our universities at present is neither related to nor determined by the demand and priorities of the Nigerian economy, society and polity, and therefore cannot be relied upon for achieving Nigeria's overall objectives in Research and Development (R\&D).

To recap, the discussion above indicates that the bulk of the research outputs carried out in Nigerian universities have low values and profiles. Though before the late 1980s, the old generation universities were trying in terms of research, but currently, the old and the new universities are living in their past glory especially in the area of research output, and, hence, the need to be revamped.

\subsection{The Teaching}

Teaching is responsible for ensuring positive changes in the lives of students in terms of skill acquisition, mental and moral development. In order to guarantee quality assurance in teaching, highly qualified teachers or lecturers are 
expected to be employed. This should be accorded with staff development programmes of various kinds put in place to ensure self-development and self-growth of lecturers. Without quality teaching, students with bright academic performance will fail to actualize their life ambitions. University education in Nigeria today seems to lack, not only quality programmes but also dedicated and high quality teaching. This can be seen by the torrent of criticisms against the procedures and quality of graduates produced in Nigeria. In a key note address delivered at the first education summit of Oyo State held in Ibadan, Okebukola (2006) decried the quality of graduates produced in Nigerian Universities. This is not unconnected with the number of academic staff in the Nigerian universities who carry out teaching, and are below the minimum qualification expected by National Policy on Education standards. These crumbling institutions cannot produce other than poor-quality students and scholarship. The Nigerian University system is performing poorly in the area of teaching and learning, in terms of labour market absorption and employer assessments of graduate (Saint, Hartnett and Swassner, 2003). This manifests in such a way that the unemployed graduates are not creative enough to create job for their survival.

Generally, only about $10 \%$ of the 130,000 students that graduate from Nigerian Universities annually are able to secure paid employment (Federal Ministry of Education, 2009). This is partly due to the quality of teaching that they received from the various universities attended. The lost of confidence by both the public and private employers of University graduates due to poor teaching and research from the Nigeria Universities has been pointed out by Dabalen, et al cited in (Olawale 2013). They reported that employers believe that Nigerian University graduates are poorly trained and unproductive on the job. This tends to negate the tenet of University education which is essentially an industry established to produce a quality workforce for national development. The lost of confidence in the Nigeria university teaching prompted the massive exodus of Nigerian to foreign universities outside the country. For instance, Educational Fact Sheet (2012) reported that "Nigeria was the 17th largest source of international undergraduates and the 19th largest source of international graduate students in the U.S. in 2009/2010". In the nutshell, the quality of teaching from the Nigerian university is not encouraging a knowledge construction economy and scholarship and above all confidence in the Nigerian universities.

\section{Analysis of the Factors Responsible for the Pitfall in Research and Teaching}

\subsection{Infrastructural Facilities}

The provision of adequate resources and their efficient utilization are factors that determine the quality of education in any country. The quantity and quality of infrastructural facilities available for teaching and research in our Universities go a long way in determining the quality of our university education. Students need to have all the basic infrastructure and conducive environment for active learning to take place. Unfortunately, infrastructures are in poor states in the Nigerian university system.

Salisu in her study on the influence of school physical resources on students' academic performance cited in Udida et al (2009) concludes that, there is significant difference in the academic performance of students in institutions with adequate facilities and those with inadequate facilities. The lack of good buildings or funds to rehabilitate collapsed structures poses threat to the system performance and its sustainability hence education to some extent is falling due to low standard. National University Commission (2006) reported that facilities in the Nigerian universities are in poor shape. The available physical facilities are severely overstretched and ill-maintained. Hence, with this development, quality seems not to be guaranteed in teaching and research of such universities.

The report of presidential visitation panels which looked into the operations of all Federal Universities between 1999 and 2003 also attested that academic and physical facility at all Universities in Nigeria were in deplorable states with insufficient lecture theatre/halls, laboratories among others (NUC, 2005). In the same vein, "over 70 percent of the laboratory equipment and library books in today's Nigerian universities, for example, were bought and placed between 1960s and 1980" (Nigeria university systems Chronicle cited in Ogu, 2008). Federal Ministry of Eduction and Okebukola cited in Oyaziwo etal (2012) reported that about 15-30\% of the infrastructure, equipment and books are non-functional, obsolete or dilapidated in the Nigeria universities. Furthermore, the classrooms, laboratories and the general environment of most universities in Nigeria are still far from a state that will promote optimal learning, teaching and research.

Importantly, a good number of Nigerian universities are offering technological education programmes. The question is how many of these universities have the basic infrastructure to run the programmes. For example, in most universities offering computer course, students graduate without touching a computer (Ogu, 2008). Odetunde (2004) did not also mince words when he said that "Unfortunately, today students are learning in dilapidated buildings, environmentally depressing and learning disabling situations. For students, it is simply a means to acquire certificates, and not the development of their cognitive and social powers. 


\subsection{Staffing}

The strength of good education in any educational [university] institution depends on the quality of the academic staff. This is because, there is no satisfactory substitute for competent staff that possesses sound educational philosophy and dynamic leadership, (Anderson and Van Dyke in Nakpodia, 2011). There are academic staff shortages in all areas, particularly in the critical areas of science and technology. Apart from the above, over $60 \%$ of academic staff in the Nigerian university system is in the category of lecturer one and below due to inter and intra-sector brain drain (Nigeria Education Fact Sheet, 2012). In a more explanatory statistics, a Director, Tertiary Education, Federal Ministry of Education, Shu'ara (2010) corroborated the foregoing that among the academics staff of the Nigerian universities in 2007 System Wide Audit, Professors/Readers were 5483(20\%), Senior Lecturers were $6475(23.6 \%)$ and lecturer one and below were 15,436 (56.4\%). The total staff strength of the universities in Nigeria within this period according to Shu'ara was 99,464 . Out of these figure, 72,070 were non-academics, whereas, 27,394 were academics staff. The ratio of the academics to the non-academic staff in the university Wide Audit within this period was 1:2.6. Shu'ara regretted that academic staff was not only bottom heavy, but in a drastic shortfall. He explained that according to the 2007 System Wide Audit, the required number of academic staff was 50,000. But only 30,457 were available. This represents a shortfall of 19,548(39.1\%). In another scenario, NUC maintains that between 1987/1988 and 1997/98 academic years, students enrolment increased by 12\% annually, while staffing growth was just 3\% a year (NUC, 2002). During this period, academic staff increased from 9,612 to 13,315 with the total student enrolment doubled from 130, 731 to 267,700. By the year 2000, student enrolment had reached 323,299, while academic staff numbers totaled 13,760, with overall staff student ratio fallen to 1:24, National University Commission cited in (Abdulkareem and Oyeniran 2011). This has negative implications on the quality of teaching and learning as well as research.

\subsection{Funding}

When education is not sufficiently funded, the nitty-gritty of such education will be weak; accordingly the products of such educational system will be generally weak academically. Reiterating the importance of funding to the educational system, Ajayi and Ekundayo (2007) opined that funds allocated to higher education should not be considered as mere expense, but as a long-term investment of immense benefit to the society as a whole. Apart from the poor quality of research and teaching as a result of poor physical facilities and staffing, another critical factor that accounts for the decline in the quality and quantity of university research and teaching output is the under-funding of the university educational institutions in Nigeria. Over the years, this problem has been generating a lot of strife between the Academic Staff Union of the Universities (ASUU) and the government. Tracing the history in the under-funding of the Nigerian university education between 1986 to year 2000, Idumange and Nanighe (2006) asserted that funding has been below the required UNESCO benchmark for African universities. The figures presented randomly between the periods were: 1986 was $\$ 999.0 \mathrm{~m}(7.9 \%), \$ 3,3999.0 \mathrm{~m}(8.3 \%)$ in $1989, \$ 1,166.0 \mathrm{~m}$ (1.8\%) in 1991 and $\$ 62,600$ (7.0\%) in year 2000. These were the percentage of the budgetary allocation to the university education in Nigeria within the period. These percentages were not even up to half of the UNESCO standard for university in the African continent. Despite the shortfall in budgetary allocation to the university system, substantial amount of the funds that are allocated to university is gulped by recurrent expenditure. For instance, between 1999-2009, a total of $\$ 651,777,180,333.33$ was allocated to federal universities. Out of this amount, only a paltry of $74,054,074,425.10$ was earmarked for capital project. A large sum of $\$ 577,723,105,913.23$ was spent on recurrent expenditure (Shu'ara, 2010). This statistics shows that bulk of the budgetary allocation to the university system in Nigeria are utilized for recurrent expenditure at the expense of capital projects. This also has negative implications on research and teaching within the university system. Again in Nigeria, the National Policy on Science and Technology (NPST) recommended 5\% of GNP to be set aside for research, but Nigeria's federal university system is said to spend only $1.3 \%$ of its budget on research (Harnett, cited in Yusuf, 2012). This also spells doom for research and teaching in the Nigerian university system.

\section{Discussion}

The findings from documentary evidence showed that the quality and quantity of research and teaching in the Nigerian universities are negatively affected by barriers emanating from lack of infrastructural facilities, poor staffing and funding. These factors interact to produce ill-fated research and teaching in the Nigerian university system.

In the first instance, the inability of the Nigerian government to objectively accept and implement the $26 \%$ funding formula for education recommended by the UNESCO impact negatively on the performance and sustainability of university education in Nigeria. Thus, it has become apparent that Nigerian government's disregard of the funding 
formula is highly damaging to higher educational institution performance and development aspiration as quality performance is the veritable instrument for the sustenance of education system. This neglect has further precipitated crises in the entire university educational system as effective teaching, research and service are no longer taking seriously. Motivation to do research and publication is very low. Research grants, though available, are not sought, since nothing new is found in most of our academic system. The research funding is also not only inadequate, but the disbursement left much to be desired. Yusuf (2012) agreed with this view when he posited that:

in the Federal Universities, routine funding from budgetary allocations is channeled through the National University Commission (NUC), which then disburses the funds to the University Boards of Research at the institutional level. However, research votes from the NUC were not disbursed regularly, and when disbursed, were often grossly inadequate to cater for the research needs of the large number of public universities in the country.

Also quality of teaching, learning and adequate supervision has equally fallen due to inadequate staff. The deteriorating quality of teaching is inevitable because over $60 \%$ of academic staff in the Nigerian university system is in the category of lecturer one and below. This is largely due to inter and intra-sector brain drain. The senior academics with wealth of experience to give academic leadership are not available. The short fall has equally shoot up the teaching load of departments taking into account the number of hours taught by a lecturer on graduate and undergraduate programmes plus hours for supervising students' projects. This has always been on the high side due to the low ratio of lecturers to the students. The consequence of this ugly scenario is mass exodus of Nigeria citizens to foreign countries where they will receive better education. For instance, Nigeria is the largest source of students from sub Saharan Africa to the U.S. There are 6,568 Nigerian students studying in over 733 regionally accredited U.S. colleges and universities in all 50 states, plus the District of Columbia. Texas is the most popular state for Nigerian students, followed by New York (Nigeria Education Fact Sheet, 2012).

Despite the mass exodus, there has been steady increase in student enrollment on yearly basis without corresponding boost in the number of lecturers and infrastructural facilities. It has reached the extent that students hang around the windows to receive lectures in some Nigerian universities due to inadequate physical facility like classroom. The lack of infrastructural facilities has also negative consequences on teaching and research activities of the universities. Supporting this assertion, Omoifo, Badmus, and Awanbor in their study cited in Chiemeke et al (2008) found that graduates of Nigerian universities rated supervised practical work and quality of academic advice received as very poor. Among graduates of medicine and sciences, only 29 percent rated equipment, laboratories, and workshops as very good. On the whole, graduates felt that teaching facilities and infrastructure were the worst aspects of the university environment, followed by staff qualifications and living conditions. The decline of staff quality is a consequence of obsolete research facilities. Laboratories that would have enhance the qualities of lecturer and students are not well-equipped or are practically non-existent. It is unfortunate that universities in Nigerian offer computer science courses without computer laboratories, let alone internet connectivity for training lecturers and students.

\section{Conclusion}

It cannot be disputed that several factors such as poor curriculum, negative attitude to work, lack of conducive environments, poor communication system are some of the factors inhibiting progress of research and teaching in the Nigerian university system. However, this paper concludes that in as much as these factors constitute as barriers to research and teaching in the Nigerian university system, the most pronounced are poor infrastructural facilities, inadequate staffing and poor funding. The argument is that, the above mentioned factors and the extent to which the affect the growth and development of the university system can easily be moderated on the proviso that infrastructural facilities, funding and staffing are adequate. The issue of poor curriculum, negative attitude to work, lack of conducive environments, poor communication and so forth may not arise provided infrastructural facilities, proper staffing and funding are in the right mix. Building on the foregoing argument, the following recommendations are made.

\section{Recommendations}

\subsection{Infrastructural facilities}

Adequate and modern facilities are urgently needed in the Nigerian university system. These facilities will certainly provide conducive environment for research and teaching in the Ivory Towers. Modern class rooms, computers, modern teaching materials, libraries, etc are some of these modern facilities that are needed. The role of library in particular cannot be overemphasized in quality teaching and research. Most university libraries in Nigeria have to be 
rehabilitated. There is urgent need to replace obsolete materials in the libraries. Working tools like laptops connected to internets are needed in the libraries to enable access of students and lecturers to the global world in the course of research and teaching. Again, effective and functional ICT should be developed for all Universities to facilitate research and teaching. With the ICT, teachers will be able to teach, communicate, maintain good records and evaluate students. As it is a well known fact that ICT is stemmed by electricity, alternative means of generating stable power (electricity) should be considered in the face of erratic power supply in Nigeria. Stand-by generator/plant should be purchased. Moreover, workshops for practical-oriented disciplines needed to be constructed.

\subsection{Funding}

Products of every university in Nigeria will be weak intellectually if adequate funds are not made available. Just as it is important for government to allocate more funds to university education in Nigeria, individual universities must collaborate and partner with Universities abroad under the partnership for Higher Education in Africa. Such partnership will open windows of co-funding certain programmes, support capacity building efforts and promote quality research. Again, creativity in the area of generation and utilization of Internally Generated Revenue (IGR) should be taken cognizance of by the management of the respective universities. Funds generated from the IGR should not be used for only recurrent expenditures, but a large chunk of it should go into capital projects that will enhance quality teaching and research.

\subsection{Staffing}

Positive changes in the quality of research and teaching in every educational institution is dependent on the quality of teaching staff. Best and quality lecturers should be recruited irrespective of their religious or tribal affiliation. A great deal of efforts to get the staffing structures right is recruiting the right people and ensuring that they are continually supported through structured training and development programme. Attracting high caliber of staff with good salary and better conditions of service is essential. High quality teaching staff and students in the universities will attract grants, endowments and fellowships needed to promote scholarship and sustain excellence. Better conditions of service will also stem the brain drains and revert to a much needed process of brain gain.

\section{References}

Abdulkareem A.Y \& Oyeniran S. (2011). Managing the Performance of Nigerian Universities for Sustainable Using Data Envelopment Analysis (DEA). Ilorin Journal of Sociology, 3(1), 37-50.

Ajayi, Isaac. A \& Ekundayo Haastrup T. (2008). The Deregulation of University Education in Nigeria: Implications for Quality Assurance. Nebula 5.4.

Aluko A.Y \& Aluko O. (2012). Human Capital Development: Nigeria's Greatest Challenge, Journal of Management Policy and Practice vol. 13(1).

Cetto, A. (1998). Scientific Journal Publishing in the Developing World, India:Lesotho Coasted, Chennas

Chiemeke S; Longe O.B; Longe F.A; \& Shaib I.O. (2008). Research Outputs from Nigerian Tertiary Institutions: An Empirical Appraisal. Library Philosophy and Practice Available from: http://libr.edu/LPP/chiemeke-longe-longeshaib.htm

Educational Fact Sheet. (2012). Economic Section, United States Embassy in Nigeria, Abuja: Plot 1075, Diplomatic Drive Central Area FCT.

Federal Ministry of Education. (2009), Roadmap for the Nigeria Education Sector. Abuja: FME.

Federal Republic of Nigeria. (2004). National Policy on Education. Lagos: NERDC

Hartnett .T. (2000). Financing Trends and Expenditure Patterns in Nigerian Federal Universities: An Update. Unpublished report. Washington, D.C.: The World Bank.

Idumange J. \& Nanighe M.B. (2006). Private Universities in Nigeria: Implications for Quality Control, Being a Paper Presented at the 30th Annual Conference of the Nigeria Association for Education Administration and Planning (NEAP)at the Faculty of Education Hall, Enugu State University of Science and Technology, Enugu.

Karani, F. (1997). Higher Education in Africa in the 21st Century. Paper presented at the Africa Regional Consultation Preparatory to the World Conference on Higher Education, Dakar, Senegal.

Magida A.Y. (2013). Historical Development of Universities In Nigeria: Chronology and the Journey So Far, available from: http://yusufmaigida.com.ng/category/scholastic/ 
Nakpodia, E.D. (2011). A Critique of the Methods of Evaluating the Competency of Lecturers in Nigerian Tertiary Institutions, African Journal of Education and Technology, Volume 1 Number 1, pp. 53-59.

National Universities Commission. (2002). Report on the Performance of Federal University System. Abuja: NUC.

National University Commission. (2005). The Role of National Universities Commission in Quality Assurance in Nigerian universities. Nigerian University System 12 (1).

Nduka, O. \& Falayojo, W. (1985). An Assessment of Performance of Nigerian Scientists in Ukoli, F. M. A. ed., What Science, Ibadan: Heinemann Books

NUC. (2006). Webometric Ranking of World Universities: Matters Arising. Monday Memo NUC, Abuja, VOL.5 (11);1-10.

Odetunde C. (2004). The State of Higher Education in Nigeria. Available athttp://wwwnigerdelter congress.com/sarticle/state of higher education.

Ogu E. (2008). Challenges Facing Nigerian Universities, Baltimore, MD,USA, Available at http://nigeriaworld.com/articles/2008/sep/300.html.

Okebukola, P. A. (2006). Intensive Retraining Programme for Graduates of Universities for Better Quality and Standards. A Keynote Address at the First Oyo State Education Summit, Ibadan. Nigeria.

Olawale Oladipo Adejuwon, Mathew Olugbemiga Ilori \& Olubunmi Felix Owoso. (2013). Meeting the Demand for Post-Secondary Education in Nigeria: Issues and Challenges journal of Sustainable Development in Africa, Volume 15, NO. 4 Clario University of Pennsylvania, clarion Pennsylvania.

Oyaziwo A., Philip O., \& Justina S.I. (2012). Increasing Access To University Education in Nigeria: Present Challenges and Suggestions for The Future The African Symposium: An online journal of the African Educational Research Network Vol.12 NO. 1.

Oyeneye, O.Y. (2006). Current Issues in the Administration of University Education in Nigeria, Lecture Delivered at the 15th Convocation Ceremony of the University of Ado Ekiti on March 29.

Saint, W., Hartnett, T. A. \& Strassner, E. (2004). Higher Education in Nigeria: A Status Report. World Education News and Reviews.

Shu'ara J. (2010). Higher Education Statistics- Nigeria Experience in Data Collection, Being a Paper Presented at the UNESCO Institute of Statistics in Anglophones Countries, Windhoek 17th-21st October, 2010.

Task Force on Higher Education and Society. (2000). Higher Education in Developing Countries: Peril and Promise. Washington, D. C: The World Bank.

Udida L.A, Bassey U.U, Udofia I.U, \& Egbona E.A. (2009). System Performance and Sustainability of Higher Education in Nigeria, Being a paper presented at the 11th International Conference of Educational Management Association of South Africa (EMASA) 7th - 9th August 2009

Yusuf, A.k. (2012). An Appraisal of Research in Nigeria's University Sector, in Journal of Research and National Development 10 (2), ISSN 1596 - 8308. Available from: www.transcampus.org./journals, www.ajol.info/journals/jorind. 